Journal of Contemporary Educational Research

Research Article

\title{
Research on the Development of School Football Competition System for Youth in Chongqing
}

\author{
Yun Liu ${ }^{1 *}$, Yiming Yang ${ }^{1}$, Xia Wang ${ }^{2}$ \\ 'Chongqing Vocational College of Applied Technology, Chongqing 401520, China \\ ${ }^{2}$ Southwest University, Chongqing 400700, China
}

\begin{abstract}
This study analyzes the current situation and problems of the school football competition system in Chongqing through literature search, interviews, and questionnaires. With this, a development model suitable for the establishment of a school football system for young people is proposed. Besides, this study aims to promote the construction and improvement and boost the competitiveness of school football competition system.
\end{abstract}

Keywords: Youth; School football; Competition system

Publication date: September, 2020

Publication online: 30 September, 2020

*Corresponding author: Yun Liu, 1bb863@163.com

On $8^{\text {th }}$ March 2015, the "Overall Plan for Chinese Football Reform and Development" was officially announced by the State Office [2015] No. 11, clarifying the strategic significance of football at the national level and making a milestone e in the history of Chinese football. Since $18^{\text {th }}$ National Congress of the Communist Party China (CPC), CPC Central Committee, with Comrade $\mathrm{Xi}$ as general secretary, had emphasized on the revitalization of football as an important task in developing sports and building a strong sporting nation. Premier Li attached great importance to football and other sports in the sport industries, and the State Council has conducted many research and deployments, leading an unprecedented opportunity for the reform and development of football in China. The sport of soccer has a wide social influence and is loved by the masses. The development and revitalization of football is of great significance for improving the physical fitness of the people, enriching cultural life, promoting patriotism and collectivism, fostering sports culture, developing the sports industry and achieving the dream of a strong sports nation, as well as promoting economic, social and cultural development. The revitalization of football is an inevitable requirement for building a strong sporting nation, and is also the ardent desire of the people. Steadfastly pushing forward reform, breakthrough in the revitalization of football industry is the practical action in the sports frontline to implement the spirit of the 18th CPC National Congress and the 2nd, 3rd and 4th Plenary Sessions of the 18th CPC Central Committee, meeting the new expectations of people, elevating the sport image of China, and achieving the dream of the strongest sport nation in the country. Therefore, strengthening the football system is important, especially the youth football system. Besides, the establishment of university, primary and secondary school and university campus football teams was promoted, with improving the available systems, applying on university, high school, junior high school and primary school football competition system, exploring the inclusion of the results of high school football competition results as the assessment of applying university sports work. Therefore, this paper investigates the current status of the development of school football competitions for youth in China, and seeks to enhance the construction and development model of the school football competition system for youth in China.

\section{Subjects and Research Methods}

This paper investigates the current situation of the school football competition system in the main urban area of Chongqing using literature search, questionnaire 
surveys, mathematical and statistical methods, and interviews. A questionnaire survey was conducted to relevant experts, leaders, administrators and coaches to obtain a wider range of opinions and suggestions. The "Research Questionnaire on the Youth School Football Competition System" was developed to understand the situation of the school football competition system for youth.

\section{Survey on the current situation of school football competitions for youth in Chongqing City}

\subsection{Current Situation of Youth School Football in Chongqing City}

After years of development, school football activities for young people in Chongqing have been initiated, and the amount of participants in school football is increasing. As one of the first cities in the country to lay out youth school football activities, Chongqing has been at the forefront in the training of football reserve talents. The Chongqing Football Reform and Development Implementation Plan (2016) proposes to strengthen the competition system, by establishing a "threedimensional" competition system for school football, social football, amateur football and professional football, and gradually form a stable, definite and orderly football competition pattern. Besides, the football competition will spread throughout urban and rural areas.

In present, Chongqing city has developed more than 500 youth football schools as compared to about 200 schools in 2015. The amount of youth who plays football has risen from 20,000 participants three years ago to 500,000 participants recently. Meanwhile, the city's school football feature schools conduct one football lesson per week, carry out two football activities, the vast majority of classes above the third grade of primary school also established various teams based on classes, grade and school. Currently, the Chongqing city has nearly 20,000 class teams, 5,000 grade teams and 800 school teams. The school football tournament, from the preliminaries of each district and county, has competed to the main city, such as Yuxi, Yuzhang, Yuzhangdong and Yuzhangdong northeast area tournaments. About 5,000 matches with up to 30,000 participants were involved. Overall, there is a gradual increase in the number of schools having school football, the number of teams involved, the number of participants and the facilities available for football activities.

\subsection{Current Situation of School Football Grounds for Youth in Chongqing City}

In stadium construction and investment in school football, years of development with the startup capital of merely $\$ 56$ million in 2015 has led to the development of 60 new school football fields (including 18 11-a-side pitch, 20 pieces of the 7-a-side pitch, and 22 5-a-side pitch) in Chongqing city. The city has expanded 40 pieces of school football fields and maintained 50 pieces of school football fields. The city plans to renovate, repair or build 1,400 new school football fields by 2020 , with a planned investment of nearly $\$ 2$ billion.

\subsection{Main forms of school football competitions for youth in Chongqing}

The new school football programme aims to promote football knowledge and skills among young people in universities, high schools, and primary schools, and to nurture football talents in schools. According to the survey, Chongqing schools at all levels are being supportive of the development of school football. It is mainly achieved through physical education classes, extracurricular sports activities, after-school sports training and after-school sports competitions, while its main competitive form is mainly reflected through 5-a-side pitch and 11-a-side pitch football.

\subsection{Survey on the Current Situation of Youth School Football Coaches in Chongqing City}

According to the survey, the city recruited nearly 500 new full-time football coaches through various methods and excellent teachers who underwent national training for more than thousand times, municipal training for more than 2,000 times, and district and county training for more than 3,000 times. Moreover, the survey involved more than 30 outstanding football coaches who were trained in France, Germany, Spain and other places. As shown in Tables 1 and 2, the current level of school football coaches in Chongqing is relatively low, and most coaches were lacking professional experience. Professionally born coaches were $36.45 \%$ while nonprofessionally born coaches were $41.46 \%$. Furthermore, the percentage of retired athletes, as well as other coaches, was $3.74 \%$ and $26.17 \%$, respectively. The majority of these coaches have attended professional 
training but have low technical skills, with $58.88 \%$ of them having a D-level certificate, which is a relatively large proportion. Meanwhile, only $3.75 \%$ of the coaches were professional coaches. Besides, there were 12.21\% of coaches had obtained certificate level A, $14.95 \%$ of coaches had obtained certificate level B and $12.21 \%$ of coaches had obtained certificate level C.

Table 1. Sources of school football coaches in chongqing

\begin{tabular}{lcc}
\hline SOURCE SPECIFIC & $\begin{array}{c}\text { NUMBER } \\
\text { (PERSONS) }\end{array}$ & $\begin{array}{c}\text { proportion } \\
(\%)\end{array}$ \\
\hline $\begin{array}{l}\text { Sports college football } \\
\text { NON-FOOTBALL MAJORS }\end{array}$ & 39 & 36.45 \\
$\begin{array}{l}\text { IN SPORTS COLLEGES } \\
\text { RETIRED FOOTBALL }\end{array}$ & 44 & 41.46 \\
$\begin{array}{l}\text { PLAYERS } \\
\text { OTHER }\end{array}$ & 4 & 3.74 \\
\hline
\end{tabular}

Table 2. School football coaching grades in Chongqing

\begin{tabular}{ccc}
\hline $\begin{array}{c}\text { CERTIFICATE } \\
\text { LEVEL }\end{array}$ & $\begin{array}{c}\text { NUMBER } \\
\text { (PERSONS) }\end{array}$ & $\begin{array}{c}\text { PROPORTION } \\
(\%)\end{array}$ \\
\hline $\mathrm{A}$ & 12 & 12.21 \\
$\mathrm{~B}$ & 16 & 14.95 \\
$\mathrm{C}$ & 12 & 12.21 \\
$\mathrm{D}$ & 63 & 58.88 \\
$\begin{array}{l}\text { PROFESSIONAL } \\
\text { COACH }\end{array}$ & 4 & 3.75 \\
\hline
\end{tabular}

\section{Analysis of the problems of Chongqing youth school football competition system}

\subsection{Analysis of the Organizers of Chongqing Youth School Football Competition}

As shown in Table 3, Chongqing school football competitions were played at different levels, with a huge gap between the popularity of schools at different levels and the basic skill level of student football, as well as different levels of participation, often resulting in disparate competitive scores. Due to the relatively large geographic differences in Chongqing, geographical influences can easily restrict the school football matches, thus school football matches were mainly underfunded by $58.88 \%$ of school matches, mainly due to the relatively inconsistent funding of football by schools. The second main concern was the students' safety issues in the participation of competition, which accounted for $51.40 \%$, mainly because students were prone to injuries, such as physical confrontations and travel safeties, during competitions. Traffic inconvenience accounted for $33.65 \%$, mainly due to regional crossing in college students participating in sports competitions. Thus, a long travel period was needed and traffic safety hazards were concerned. In addition, unreasonable competition time arrangement accounted for $29.91 \%$, mainly due to the schedule that Chongqing campus football game set from Monday to Friday, which greatly affected $\mathrm{s}$

Table 3. Factors Influencing The School Football Competitions In Chongqing City

\begin{tabular}{llllll}
\hline \multirow{5}{*}{ Factors } & TRAFFIC & $\begin{array}{l}\text { UNREA- } \\
\text { SONABLE }\end{array}$ & & & \\
& INCON- & COMPETI- & UNDER- & STUDENT & \\
& $\begin{array}{l}\text { VE- } \\
\text { NION TIME }\end{array}$ & FUNDED & $\begin{array}{l}\text { SAFETY } \\
\text { ISSUES }\end{array}$ & OTHERS \\
& ARRANGE- & & & \\
MENT & & & \\
\hline $\begin{array}{l}\text { PERCENT- } \\
\text { AGE (\%) }\end{array}$ & 33.65 & 29.91 & 58.88 & 51.40 & 14.95 \\
\hline
\end{tabular}

\subsection{Organization of Chongqing Youth School Football Competition}

At present, the different levels of competition management in school football competitions has occurred in Chongqing city. Besides, there is a discrepancy in referee efficacies as they are recruited mostly from physical education teachers selected by football association (FA), professional referees appointed by FA and some professional football students. As shown in Table 4, the phenomena shown in the Chongqing football competition are the disparity between competitors (70.09\%), forfeited competitions $(33.65 \%)$, referee biasness $(33.65 \%)$, and "big teams beat small teams" (29.91\%).

Table 4. Phenomena of chongqing school football competition.

\begin{tabular}{lcc}
\hline $\begin{array}{l}\text { Phenomena of school football } \\
\text { competition }\end{array}$ & $\begin{array}{c}\text { Number } \\
\text { (persons) }\end{array}$ & $\begin{array}{c}\text { PROPORTIONS } \\
(\%)\end{array}$ \\
\hline $\begin{array}{l}\text { "BIG TEAMS BEAT } \\
\text { SMALL TEAM" }\end{array}$ & 32 & 29.91 \\
$\begin{array}{l}\text { DISPARITY BETWEEN } \\
\text { COMPETITORS }\end{array}$ & 75 & 70.09 \\
$\begin{array}{l}\text { FORFEITED COMPETI- } \\
\text { TION }\end{array}$ & 36 & 33.65
\end{tabular}


Table 5. Problems in school football competition arrangements

\begin{tabular}{|c|c|c|c|c|c|c|c|}
\hline \multirow[b]{2}{*}{$\begin{array}{l}\text { PROBLEMS WITH } \\
\text { COMPETITION AR- } \\
\text { RANGEMENTS }\end{array}$} & \multirow[b]{2}{*}{$\begin{array}{l}\text { LACK OF } \\
\text { VENUE }\end{array}$} & \multicolumn{3}{|c|}{ LESS TIME } & \multirow[b]{2}{*}{$\begin{array}{c}\text { LESS AT- } \\
\text { TENTION } \\
\text { FROM } \\
\text { LEADERS }\end{array}$} & \multirow[b]{2}{*}{$\begin{array}{l}\text { LOW PAR- } \\
\text { TICIPATION } \\
\text { NUMBERS }\end{array}$} & \multirow[b]{2}{*}{ OTHERS } \\
\hline & & $\begin{array}{c}\text { LACK OF } \\
\text { FOCUS } \\
\text { FROM } \\
\text { LEADERS }\end{array}$ & $\begin{array}{c}\text { SCHED- } \\
\text { ULED FOR } \\
\text { STUDENT } \\
\text { COMPETI- } \\
\text { TION }\end{array}$ & $\begin{array}{l}\text { LACK OF } \\
\text { FUNDING }\end{array}$ & & & \\
\hline BELGIUM （\%) & 51.40 & 62.62 & 81.31 & 88.79 & 73.83 & 47.66 & 18.69 \\
\hline
\end{tabular}

Table 6. Factors influencing the development of school football competitions.

\begin{tabular}{|c|c|c|}
\hline Factors influencing the development of school football competitions & Number (persons) & PERCENTAGE (\%) \\
\hline INADEQUATE COMPETITION FUNDING & 51 & 47.66 \\
\hline LACK OF ATTENTION FROM LEADERS & 47 & 43.93 \\
\hline INADEQUATE EQUIPMENT AND FACILITIES & 31 & 28.97 \\
\hline LACK OF PARENTAL SUPPORT & 47 & 43.93 \\
\hline INADEQUATE ORGANIZATION STRUCTURE & 31 & 28.97 \\
\hline INCONSISTENT IN THE REFEREE JUDGEMENTS & 12 & 11.22 \\
\hline OTHERS & 12 & 11.22 \\
\hline
\end{tabular}

REFEREE BIAS

36

33.65

\subsection{The Problems and Arrangements Faced by Chongqing Youth School Football Competition}

Based on the interviews and surveys of school football competition arrangements in Chongqing, the main factors influencing school football competition arrangements include: the lack of venue, unbalance in player levels, less time scheduled for the student competition, lack of funding, lack of leadership focus, and inactive in participation. As shown in Tables 5, "lack of funding" accounted for $88.79 \%$, "less time scheduled for student competition" accounted for $81.31 \%$, and "lack of focus from leaders" accounted for $62.62 \%$, of these factors influencing the arrangement of school football competitions. Furthermore, "less attention from leaders" accounted for $73.83 \%$, "lack of venue" accounted for $51.40 \%$, "low participation numbers" accounted for $47.66 \%$, while other factors accounted for only $18.69 \%$. Overall, the process of scheduling football competitions is greatly influenced by the lack of funding, the lack of time for students to play, and the less attention of leaders. As shown in Table 6 , the development of school football competitions

in Chongqing is mostly influenced by three factors, namely inadequate competition funding $(47.66 \%)$, the lack of parental supports (43.93\%), lack of attention from leaders $(43.93 \%)$, inadequate equipment and facilities $(28.97 \%)$ and inadequate organization structure $(28.97 \%)$. Finally, the inconsistent in the referee judgements and other factors each accounted for approximately $11.22 \%$.

\section{Conclusion}

As the mainstay of school football activities, the youngsters are not given sufficient focus. Therefore, it is important to establish the competition goal as the core of the competition system and the competition resources as the premise and foundation of the competition system in the cultivation of the football competition system. A complete competition system should have clear competition goals, form a systematic competition system and formulate scientific rules and regulations to fully utilizing competition resources and environment. With the focus on the youth school football competition, this enables the development of novel China youth school football system.

\section{References}


[1] Notice of the General Office of the State Council on the Issuance of the Overall Plan for the Reform and Development of Football in China. State Council of the People's Republic of China Bulletin, 2015: 47.

[2] Li WD. Research on the competition system of football in Chinese youth schools [D]. Shanghai Institute of Physical Education, 2012.

[3] Chen J, Hu DP. Research on the classification of youth school football competitions[J]. Contemporary Sports Technology, 2017(7): 182.

[4] Li XR. Research on the development model of youth school football competition system[J]. Contemporary Sports Science and Technology,2017(28).

[5] Li WD, He ZL, Dong ZM. Construction of the development model of youth school football competition system[J]. Journal of Wuhan College of Physical Education, 2013(2): 88-93.

[6] Liu R. Research on the system of youth school football competition in Beijing[D]. Capital Institute of Physical Education, 2018.

[7] Dong J. Research on the guarantee system of youth campus football league in Inner Mongolia Autonomous Region [D]. Beijing Sport University, 2018.

[8] Xu L. Discussion on the development model of Hainan youth school football competition system[J]. Contemporary Sports Science and Technology, 2015(14): 207-209.

[9] Li WD, He ZL. Research on the reform and innovation of Chinese youth school football competition [C].

[10]Feng AM. Research on the development strategy of the fourth-tier school football league in Liaoning province[J]. Liaoning Sports Science and Technology, 2016(3): 17-21. 